\title{
Post-Fordist Capitalism in the Czech Republic: The Investment of Flextronics in Brno
}

\author{
JAN DRAHOKOUPIL* \\ Central European University, Budapest
}

\begin{abstract}
Drawing on the author's case study of one 'unsuccessful' attempt of the Czech Republic and Brno to lure foreign capital to the city of Brno, this article attempts to provide incentives for rethinking the theories of post-Fordism in order to theorise about the particular, local articulation of capitalism(s) in East Central Europe. The author presents selected findings from the case study with the intention of introducing and demonstrating the utility of the form-analytic, strategic-relational approach and some of the post-Fordist theories in analysing capitalism and socio-economic governance in the Czech Republic. He draws on the case of the subsidised investment in the Brno region by the transnational corporation Flextronics in 2000-2003. The company left the locality after approximately two years, an unprecedented occurrence in the Czech Republic, which resulted in some political upheaval. The author focuses on the interaction between the investor and the state and other bodies of socio-economic governance and argues that the story of Flextronics is indicative of some of the post-Fordist transformations in capitalism and capitalist governance. Further, the author also draws some conclusions with regard to the relations between company, state, and municipality in the post-Fordist environment in the Czech Republic.

Sociologický časopis/Czech Sociological Review, 2004, Vol. 40, No. 3: 343-362
\end{abstract}

\section{Introduction}

The states and societies of East Central Europe (ECE) joined the world capitalist system at a time when the system itself was struggling with a number of dilemmas and was confronted with new problems and challenges. This article deals with some of the relatively new trends in world capitalism from the ECE perspective. It presents selected findings of a case study I made of the transnational corporation (TNC) Flextronics' subsidised investment in the Brno region in 2000-2003. The company left the locality after approximately two years, an unprecedented occurrence in the Czech Republic, which caused some political upheaval. This article focuses on the interaction between the TNC and the state and other bodies of socio-economic governance. ${ }^{1}$

\footnotetext{
* Direct all correspondence to: Jan Drahokoupil, Department of Sociology and Social Anthropology, Central European University, Zrinyi u. 14, H-1051 Budapest, Hungary, e-mail: drahokoupil@email.cz

1 See, e.g, Pavlínek [1998] and Pavlínek and Smith [1998] for a discussion of the role of foreign direct investment in the Czech post-communist transformation.
}

(c) Institute of Sociology, Academy of Sciences of the Czech Republic, Prague 2004 
The aims of this article are quite limited. Alongside introducing selected empirical findings from the case study, I would also like to demonstrate the utility of the form-analytic, strategic-relational approach in analysing socio-economic governance in the Czech Republic and show the relevance of some concepts contained in the theories of post-Fordism in the context of ECE. The study should provide incentives for rethinking the theories of post-Fordism in order to theorise about the particular, local articulation of capitalism in the region. I would like to emphasise that this study does not attempt to theorise about Czech capitalism as such.

First, I will briefly outline my theoretical perspective and employ it to depict current transformations of capitalism and the socio-economic governance of capitalism. Second, I will outline some methodological remarks and caveats for this inquiry. Finally, I will present selected findings from my case study of Flextronics' investment in Brno by utilising some concepts of the form-analytic, strategic-relational approach and the theories of post-Fordism.

The story of Flextronics' investment will be interpreted as a post-Fordist type of interaction between the economic and the political systems. The efforts of the city and the state to attract Flextronics to the locality with investment incentives and the ensuing state-city-TNC interaction will be described as post-Fordist socio-economic governance. The scalar dimension of the interaction demonstrates the transformation of the political system in the process of scale relativisation.

The region and the TNC are in complexly dialectic relation to one another. There is no one-way dependence of the region on the TNC or vice versa. However, the region is in a disadvantageous position in relation to the TNC. The power of the TNC is based on the (imagined) competition between localities to attract investors. The activities of regions are continuously evaluated by investors (TNCs), which are able to reward and/or punish localities. In addition, the TNC's power is based on a situation in which the TNC is a source of uncertainty for the locality.

I conclude that the analysis of the Flextronics story supports the thesis that current spatio-temporal transformations reinforce the potential of the economic system to achieve ecological dominance - that is, to enforce its logic on other systems. The capacity to distantiate and compress time-space enabled Flextronics to escape the control capacities of the locality or nation-state. The power relation between the TNC and the locality is unequal to the region's disadvantage. In addition, it is possible to observe the semantic dominance of the economic system. The economic dominance is reflected in the language and logic that public decision-makers use to grasp social reality and in their semantic representation of the world economy. 


\section{The theoretical perspective}

\subsection{The form-analytic, strategic-relational approach}

In the study I draw on the form-analytic, strategic-relational approach developed by Bob Jessop [1990; 2002a]. This paradigm integrates (1) the regulation approach to the political economy of capitalism, (2) the political economy of state and politics inspired by Gramsci and Poulantzas, (3) critical discourse analysis, and (4) systemtheoretical insights into autopoiesis and governance. These approaches are complementary, since the first three assume critical-realist ontology, epistemology, and methodology [e.g. Sayer 2000], and the remaining, constructivist autopoieticist theories can be re-contextualised and articulated into the critical-realist paradigm.

The regulation approach rejects the existence of an ahistorically delimited and disembedded sphere of economic relations tending towards equilibrium [see, e.g., Boyer 1990; Boyer and Saillard 2002; Jessop 1990, 1995]. Market forces are viewed as one of many factors contributing to capitalist expansion. Regulationists also reject the argument that the optimising behaviour of inherently rational individuals drives exchange. Instead, the economy is understood as historically specific, socially regularised and embedded with actors that are governed by historically specific economic norms and modes of calculation. Continued capital accumulation without extra-economic support is considered improbable owing to the crisis tendencies inherent to capital relations. Capitalism is analysed very broadly as an ensemble of institutions, organisations, actions, and social forces organised around the reproduction of capital as a social relation. This ensemble acquires structural coherence as a specific 'social fix', which helps to secure, partially and provisionally, the reproduction of capitalist relations and achieves the unstable equilibria of compromise.

The political economy of state and politics inspired by Gramsci [1971] and Poulantzas [1978] which understands state power to be the power relation that is mediated through the state's institutional ensemble. State power is not exercised by the state as such, but depends on the balance of forces within society and state apparatuses. The correspondence between the different social practices that bring social forces and institutions into compliance with the requirements of capitalist reproduction (i.e. the historic bloc) may be secured by contingent and historically specific hegemonic leadership. Intellectuals who develop alternative strategies and hegemonic visions play a key role in exercising hegemony and in the construction of the historic bloc.

Critical discourse analysis contributes to the form-analytic, strategic-relational approach through its emphasis on the contribution of discourse to the construction of the capitalist economy, state, and historic bloc [see, e.g., Chouliaraki and Fairclough 1992, 1995; Fairclough, Jessop and Sayer 2003]. Nevertheless, emphasis on the discursive moment of capitalism does not imply that capitalism is constructed purely discursively or that it lacks any institutional materiality.

The theories of self-organisation provide useful insights into the relations between mutually dependent societal systems with their own logic, organisational 
principles, institutional dynamics and operational codes. Moreover, they offer theories on the relations between systems and the lifeworld. For instance, these theories produced the concept of ecological dominance, which refers to the capacity of a system to enforce its logic on other systems.

In sum, the form-analytic, strategic-relational approach views capitalist modernity from the perspective of reciprocally interdependent autopoietic societal systems. These sub-systems are structurally coupled with each other and with their environment in the process of co-evolution. Based on a Marxist analysis of contradictions in the commodity form, the self-reproduction of the capitalist economy is deemed improbable. Therefore, the capitalist economy is asymmetrically dependent on other systems, which compensate for the constitutive incompleteness of the capital relation in the real world and temporarily manage fundamental contradictions in the commodity form. Therefore, the co-evolution of societal sub-systems also involves imposing the spatio-temporal fix (or 'social fix') on the economic system.

\begin{abstract}
Reproducing and regularizing capitalism involves a 'social fix' that [...] gives it [capital relation] a specific dynamic through the articulation of its economic and extra-economic elements. This helps to secure a relatively durable pattern of structural coherence in the handling of the contradictions and dilemmas inherent in the capital relation. One necessary aspect of this social fix is the imposition of a 'spatio-temporal fix' on these economic and extra-economic elements. It achieves this by establishing spatial and temporal boundaries within which the relative structural coherence is secured and by externalising certain costs of securing this coherence beyond these boundaries. [Jessop 2000a: 334-335]
\end{abstract}

Thus, the history of capitalism is viewed as a succession of more or less effective implementations of accumulation strategies that temporarily and partially resolve or displace capital-relation contradictions.

\title{
2.2 Recent transformations of capitalism
}

In the paradigm I employ, the current stage of capitalism is interpreted as a crisis of the Fordist, national, spatio-temporal fix of the economy and polity, which was institutionalised through the advances made by capitalist societies after the Second World War [Jessop 1994; 2000a; 2000b; 2002a; 2002b]. The Fordist social fix was based on a cycle of mass production and mass consumption. This virtuous cycle rested on a congruence of national economy, national state, national citizenship, and national society.

The undermining of the nation-state containers of social and economic processes is one of the main factors that caused the crisis of the Fordist social fix. Economic internationalisation undermined the national economy as the object of economic management. The era of effective national economies and related state 
policies is over, as the nation state, national economy and national society are no longer congruent. This shift has rendered Fordist economic and social governance infeasible. It has led to a different conception of the economy. The object of economic management is no longer the nationally demarcated cycle of mass consumption and production, but rather the knowledge-driven network economy in an environment of globalisation. Success in the new economy depends on the position of economic units in the network. Accordingly, the dynamics of growth in a locality depend on its integration into the global division of labour. Therefore, state managers are concerned primarily with the economic competitiveness of a place and, consequently, with supply-side intervention [cf. Beck 2000a; Castells 1996; Cerny 1995; Jessop 2000a; Reich 1991; and others]. ${ }^{2}$

The key aspect of the current changes is the 'relativisation of scale'. The national scale of economic and political action has lost its primacy. National economies have become unmanageable using traditional methods of intervention and they have come to be more liable to crisis. With the primacy of the national scale, the nested relation between local regional and national scales has been disrupted. The process of scale relativisation, however, has not produced a homogenised global space of (not just) economic activity. It has involved both the re-ordering of scales and the emergence of new ones. However, no one scale has become dominant.

According to Jessop, the state and the political system are undergoing reorganisation towards a new regulatory framework. ${ }^{3}$ In the process of scale relativisation the powers in the political system are de-territorialised and re-territorialised - the powers located at the national level are transformed upwards (supra-regional or international level), downwards (local level), and sideways (cross-national alliances). Furthermore, there is a dialectic process of re-statisation and de-statisation - in which private and public responsibilities are redefined. Also, the division of labour and the boundaries between the economic and political systems in securing the reproduction or regulation of the capital relation are transformed (e.g. into a public-private partnership). Moreover, the nested hierarchy of state power are being re-ordered.

Jessop [2002b] has introduced an ideal-typical model of the 'Schumpeterian workfare post-national regime' (SWPR) - a model of welfare governance that substitutes for the Keynesian welfare national state. First, the Keynesian intervention is replaced by a Schumpeterian one. Its aim is to strengthen the competitiveness (entailing the promotion of flexibility and permanent innovation) of a place in relatively open economies by means of supply-side intervention. Thus, public officials enhance the competitiveness of the territory and the population through investment incentives, investing in infrastructure and education. They also employ dependency management by discriminating among different investors on the basis of their ability to contribute to local development (technology transfers, links to local sup-

\footnotetext{
2 For a counter argument to this thesis see, e.g., Hirst and Thompson [1999].

3 Tickell and Peck [1995] oppose the emergence of the post-Fordist social fix on the grounds of regulation theory. They assert that there is currently a lack of any regulatory framework.
} 
pliers, industrial upgrading). Second, SWPR can be described as a workfare regime, as it subordinates social policy to the demands of labour market flexibility and competitiveness. Thus it provides social services that benefit business and downgrade individual needs to a secondary position (e.g. the downward pressure on the social wage as a cost of international production). Third, with the increased significance of non-national scales of political action in the process of de-territorialisation, re-territorialisation, re-statisation, de-statisation, etc., one must speak not of a national but rather of a post-national regime. Finally, it does not take the form of a regime, since increased significance lies with the non-state mechanism of compensating for market failures (e.g. public-private and private-private networks).

In so far as the economic system is concerned, TNCs are often considered the principal actors in the post-Fordist situation and they have a key role in shaping local economies and societies. They owe their power to the fact that they are the central organisers of the world's production [cf. Strange 1996; Ostry 1990; Dicken 1994, 1997]. In Beck's view [2000b] the basis of the power of the TNCs lies in the following factors: First, TNCs are able to export jobs to 'cheap places' - i.e. to parts of the world where the cost of labour and workplace obligations are lowest. Second, global proximity (time-space compression and distantiation) enables TNCs to organise the production of goods and services through a division of labour in different parts of the world. National products and labels are therefore just illusions. Third, TNCs are in a position to 'play off' countries or locations against one another, as states are structurally dependent on mobile capital, while the TNCs have the freedom to choose the most favourable place of investment and production. "What is novel and decisive is not that [...] transnational corporations are growing in number and diversity, but that, in the course of globalization, they are placed in a position to play off national states against one another" [Beck 2000b: 65]. In the process of 'global horse-trading' they are able to find the cheapest fiscal conditions and the most favourable infrastructure. Moreover, they can 'punish' countries that they find unfriendly and/or expensive by withdrawing or not carrying through the investment. In this way they have the power to withdraw material resources such as capital, taxes, and jobs from society. Fourth, because of the distantiation of production, they themselves can choose their investment site, production site, taxation site and residential site. Again, the TNCs are able to 'play off' these sites against one another. As a result, they can produce in a locality with the lowest production costs and social standards and pay taxes where they are lowest, and their managers can live where it is nicest.

According to Bauman [1998a, 1998b], the power of capital is an example of Crozier's domination strategy. Michel Crozier asserted that to rule means to be a source of uncertainty in relation to the dominated. In the 'new world order', world finance, capital, the market and its actors are the focus and source of uncertainty for states. The former possess the freedom to manoeuvre, while states are exposed to the constraints which are produced by the decisions of the dominated side. Currently, freedoms and constraints have been redistributed in a manner that results in the concentration of freedom to act in the economic sphere. 
In system-theoretical terms, the current spatio-temporal transformations reinforce the potential of the economic system to achieve ecological dominance. The concept of ecological dominance refers to the potential or capacity of an operationally autonomous system to enforce its logic on other systems, structurally coupled, to an extent greater than the capacity of these systems to impose their logic on the former. ${ }^{4}$ The ecological dominance of a system is only relative and contingent and does not exclude relations of reciprocal influence, resistence and dependence of the dominant system an other systems. The processes of globalisation, and especially the neo-liberal policies connected to them, reinforce the relative ecological dominance of the capitalist economy, as they release its degrees of freedom, its opportunities for self-reorganisation, its scope for time-space distantiation and compression, its externalisation of problems and its hegemonic capacities from confinement within limited ecological spaces policed by another system (e.g. nation states). Thus, the ecological dominance of the economy is based on the abilities of economic actors to distantiate and/or to compress time-space and consequently escape the control capacities of most political forces [Jessop 2000a]. Jessop discerns five trends that strengthen the ecological dominance of contemporary capitalist economy. First, there is an increase in the complexity of circuits of capital and an increase in flexibility in its response to perturbations. Second, the deepening of spatial and scalar divisions of labour and the creation of more opportunities for capital to move up, down and across the scales enhance capital's capacity to defer and displace its internal contradictions by increasing the scope of its operations on a global scale. Third, the exchange-value moment of capital is emancipated from extraeconomic and spatio-temporal limitations at the expense of other systems (the growing separation of exchange and use values, as indicated above). Fourth, the capacity of the economy to escape the control of other systems and to follow its own procedures increases. And fifth, the capacity of nation states to confine an economic system's dynamics within the framework of the national matrix (e.g. national security or national welfare) has weakened.

\section{Methodological remarks and caveats}

As I have mentioned, this article presents selected findings from the case study of the transnational corporation Flextronics' subsidised investment in Brno. The focus of the case study is the interaction between the TNC and state and municipal bodies of socio-economic governance. The main aim of this article is to approach the case of Flextronics' investment from the perspective of the form-analytic, strategicrelational paradigm which will allow me to introduce some empirical findings and test the utility of some theories of post-Fordism in the context of ECE. It is not my

\footnotetext{
${ }_{4}^{4}$ Please note that the concept of ecological dominance is inherently system-theoretical and does not refer to Marxist economic determinism.
} 
intention in this paper to provide a systematic theory of Czech capitalism; however, I would like to contribute to a future re-thinking of the post-Fordist theories from the perspective of the Czech Republic and ECE.

Therefore, in this paper I neither attempt to test the validity of the theory in a Popperian sense, nor do I give any evidence about the extent of post-Fordist transformations of capitalism as such. Instead, this study examines the case according to the logic of 'analytic generalisation' or 'analytic induction' [Brannen 1992; Yin 1989]. In contrast to statistical generalisation, where the findings are generalised from the sample to the population, in analytic generalisation the inference is made to the theory. The theory is a level of case study generalisation, that is, the testing of theories or theory building. "[A] previously developed theory is used as a template with which to compare the empirical results of the study" [Yin 1989: 38]. Accordingly, it is not generalised to all cases, but to cases matching the same theoretical propositions - to cases "in the same situation" [Yin 1989: 38].

In the case study I used multiple sources of evidence. I analysed newspaper articles related to the story and other documents, such as reports and statistics, which were provided by the city of Brno, by CzechInvest, the governmental investment-luring agency, and by the Regional Development Agency of Southern Moravia (RDASM). In addition, I conducted semi-structured interviews with the key actors involved in the story. I interviewed a member of top management at Flextronics, two top officials at CzechInvest, and two top officials at the Regional Development Agency of Southern Moravia. The interviews covered the main actors in the story. ${ }^{5}$

The research not only provides 'objective facts' regarding the case, it also shows the actors' interpretations of the Flextronics story and its socio-economic environment. The research reveals the decision-makers' notion of the environment, their frames of relevance, the types of rationality they use, the different constraints they face, and the expectations they have. Consequently, although the analysis of this case cannot provide a general account of capitalism in the Czech Republic or the ECE, it can provide an interpretation of some key decision-makers. This image of capitalism is of crucial importance since it influences some key policy decisions.

\section{Flextronics' investment in the context of post-Fordist transformations}

\subsection{The story of Flextronics' investment in brief}

In April 2000, Flextronics, the world's leading electronic manufacturing services provider, expressed an interest in building a plant in the city of Brno. At that time, Flextronics was already present in the city, where it employed approximately 750 people.

\footnotetext{
5 The city of Brno was represented by the officials from the Regional Development Agency of Southern Moravia. Even though this agency is institutionally independent, it is connected with the city through social networks and it formulates and implements Brno's development policies (especially those relating to FDI).
} 
The investment was subsidised by the Czech Republic and by the city of Brno. The subsidies were a part of a state investment-luring policy implemented by the Ministry of Industry and Trade and its agency CzechInvest. The state subsidised the investment through income-tax reliefs (Flextronics was exempted from tax payments for ten years), subsidies for employee training, and import-duty reliefs. The state made the subsidy conditional on the obligation of the company to construct a high-tech electronics plant, invest 10 million USD, and train 225 employees. The subsidy from the city of Brno consisted of the lease of the land in the industrial zone for free, with the prospect of a free transfer of land in the near future. The city also paid for the construction of the industrial zone. Brno made its subsidy conditional on the obligation of the company to create, by 2006, a total of 3000 new jobs that would continue for at least 5 years.

Flextronics opened the plant in September 2000. The number of people employed at the plant increased quickly and reached a peak of 2200 employees in 2001. In March 2002, Flextronics started to make substantial lay-offs. The recession in the electronics industry was cited as the reason. In July 2002, the company announced that it would be closing down and shifting production to Hungary and other countries, and that it would be laying off all the employees in Brno. Only the research and development centre that employed 34 researchers was to be preserved.

The government did not demand that the investment incentives granted Flextronics be refunded, since the investment had fulfilled the government's demands: it brought money, technology, and know-how. But the situation on the regional level was much more complicated than on the national level. In August 2002, the municipal council decided to cancel the contract for the free transfer of land that it had made with Flextronics in May 2002. However, Flextronics wanted to keep the land and did not want to pay back any rent. Moreover, it wanted to complete the transfer of the remaining land. Eventually, the city of Brno and Flextronics reached a settlement in March 2003. The company kept the land under the production hall; it paid Brno rent even for land it had received for free; it gave back one plot of land; and it paid off the rent it owed. For its part, the city bought the entrance building, the parking lot, the communications and infrastructure.

\subsection{The story and its actors in the context of post-Fordist transformations}

The story of Flextronics' investment is a post-Fordist type of interaction between the political and economic sphere. We are dealing here with the typical actors in a postFordist situation and with a post-Fordist economic engagement of the political system. The investigation of the interactions between Flextronics and public bodies also demonstrates that the state itself went through a post-Fordist reorganisation. However, contrary to first impressions, this case is not an example of the intentional short-term exploitation of a region by a TNC in a post-Fordist environment.

The major players engaged in this story, i.e. Flextronics, CzechInvest, the city of Brno, and the Regional Development Agency of Southern Moravia (RDASM), are 
the principal actors typically involved in a post-Fordist situation. Flextronics is a transnational corporation (TNC), which is a dominant post-Fordist economic actor. CzechInvest, a state investment-luring agency that reports to the Ministry of Industry and Trade of the Czech Republic, represents a new kind of state engagement in the economy (cf., SWPR above), as it promotes the competitiveness of the locality and applies dependency management through a policy of investment incentives. The city of Brno is an example of a new site of power and a new subject of social policy in the post-Fordist political system. It represents the process of downward delegation of state power. RDASM represents not only a shift of state authority downward, but also a shift sideways, and the redefinition of public and private responsibilities. RDASM is a public-private body, ${ }^{6}$ i.e. a joint venture of three bodies - the Association of Municipalities and Towns of Southern Moravia, the Regional Chamber of Commerce of Southern Moravia, and the Southern Moravia Region. RDASM is also a regional branch-office of CzechInvest. It assists Brno and the entire region in formulating and implementing social policies (the shift downward) and it manages regional cross-border co-operation (the shift sideways).

The story itself is a typical interaction between a social and political system in the environment of post-Fordism. It represents a SWPR type of economic intervention. The policy of luring investment and of investment subsidies in particular is Schumpeterian supply-side intervention. CzechInvest promoted the competitiveness of the locality by relieving Flextronics of the standard obligations to the locality (tax reliefs) and subsidising its investment and labour costs (the transfer of land, the construction of infrastructure and the training of employees). Moreover, CzechInvest applied dependency management by selecting investors on the basis of their ability to contribute to local development (the state made the subsidy conditional on the company's obligation to construct a high-tech electronics plant and to train employees).

Scrutiny of the scalar dimension of the interaction between Flextronics, the state and the region further supports the thesis about the transformation of the political system in the process of scale relativisation. The autonomous, non-state, regional actors were engaged in the interactions and negotiations with the TNC, which indicates the reorganisation of the political system. This is noticeable despite the small size of the Czech Republic, especially in the context of FDI flows. Even though the very policy of investment incentives was formulated on the national level and a considerable portion of the subsidies was provided by the state, the substantial portion of the subsidies was granted by the city and negotiated on the municipal level (e.g. transfer of land). Furthermore, the contracts between Flextronics and the state on the one hand and Flextronics and Brno on the other differed. The city had different priorities than the state with regard to the possible benefits of the investment. Also, the state's and the city's negotiations with Flextronics following the company's decision to leave differed, as did their respective perceptions of the whole story.

${ }^{6}$ RDASM labels itself as a 'non-profit public-private body'. 
With regard to how the event was perceived, on the national level, the government, union leaders and most analysts remained confident that the closure of the electronics plant was an isolated event. Industry and Trade Minister Jiří Rusnok, for instance, remained bullish about the prospects for further foreign investment, saying, "One factory shuts down, but there are another ten coming" [The Prague Post 24 July 2002]. Moreover, CzechInvest calculated that the investment was of profit to the Czech Republic in terms of its financial costs and benefits. Conversely, the locality was dismayed and the departure of Flextronics caused local political turmoil. The quarrel was over responsibility for the failure, or, more appropriately, over the issue of irresponsibility. For instance, Pavel Březa (communist), an opposition councillor, stated: "I do not think that this is just a chance occurrence; on the contrary, it is the failure on the part of city officials" [Mladá Fronta Dnes, 13 July 2002]. Deputy Mayor Petr Zbytek replied that it was the social democratic government and its FDI-luring agency that recommended this untrustworthy company. The city council did not put the proposed removal of allegedly responsible officials to the vote because the municipal elections were about to come in four months. Thus, the citizens were left to judge. One of the official accused of responsibility for the investment failure defended himself by saying: "I cannot influence the global crisis. We have done everything in order to prevent Flextronics' departure from Brno. I do not think that we made any mistakes" [Mladá Fronta Dnes, 13 July 2002].

At first glance this story might seem a typical example of the (intentional) short-term exploitation of localities and the incentives that they provide by a TNC. This phenomenon, the new contradiction of post-Fordism, is often mentioned in the discussion about the consequences of the dissolution of the Fordist social fix. ${ }^{7}$ However, the following facts indicate that Flextronics' investment is probably not such a case of exploitation. First, in the end Flextronics had to pay back the subsidies that it received from the city. ${ }^{8}$ Second, the Brno adventure constituted a loss for Flextronics. And third, other explanations for Flextronics' departure are more compelling (see below).

\footnotetext{
${ }^{7}$ In particular, this phenomenon represents the spatial contradiction between the imperatives of social reproduction and economic valorisation. There is a contradiction between the notion of the mobile economy of flows and the economy as a locally embedded system comprising both economic and extra-economic resources. It enables capital to exploit local (extraeconomic) resources without contributing to their long-term reproduction and then to move elsewhere and engage in the same short-term behaviour [Jessop 2000a, 2000b].

8 There was no compensation for the state's subsidies, because Flextronics fulfilled all the obligations that had been set by the state.
} 


\subsection{Remote and local: interdependence or asymmetric dependence?}

This case study offers interesting insight into the nature of the local-remote interdependence, which results from the process of scale relativisation. The case demonstrates the complexity of a remote-local relationship. The very arrival of Flextronics contradicts the stereotypical notion of the one-way dependency of a locality on a non-local investor. In the case of Flextronics it is possible to observe the dynamics of the remote-local interaction. The impulse to carry out the investment did not come from the investor as a part of its development strategy. On the contrary, it seems that the impetus came from the local economic actors. Indeed, this investment is better understood as part of the development strategy of a local company, UTES Elektronika. In 1998 this company was doing quite well and employed about 300 employees. However, a lack of capital hampered its further development. Therefore, its owners decided to seek a 'strategic partner'. They finally succeeded when the company was bought by Devatron International, which later merged with Flextronics.

[Manager of Flextronics:]

If Flextronics were to have behaved ... normally, it would have certainly focused on Hungary. However, owing to our presence here, we were successful, we had our own projects, we had our own business development, which means ... that we were making contracts independently, in co-operation with the Flextronics network, naturally. Thus, let's say they let us do it here.

The analysis of Flextronics' departure makes the picture of local-remote dependence much more complex. The very decision of Flextronics to leave was based on remote events. It was mainly the world crisis in the electronics industry, triggered by the terrorist attacks on September 11, which led to the departure of the corporation.

\section{[Manager of Flextronics:]}

And everything was looking quite well, but then September 11 came, which ... started off the world crisis in electronics, stock-exchange problems, the fall of the dollar, the decline in purchase orders. It appeared that this segment of the economy had been typically ... overvalued, maybe speculatively, hard to say.

However the local situation did not directly reflect the world crisis. On the contrary, the local branch was 'in the black' during the decline in the world economy. The decision to stop production in Brno can only be comprehended in the context of the

\footnotetext{
${ }^{9}$ In this paper, 'local' refers basically to the national and regional scale; 'remote' refers to nonlocal - to the events that are not taking place on the national and regional scale of social and economic activities.
} 
consolidation of Flextronics' international production chain. The corporation decided to shut down production in the Brno branch because it was relatively isolated from the other production sites. The Brno branch was profitable, but nonetheless was 'in the wrong place at the wrong time'.

\section{[Manager of Flextronics:]}

... we were a profit-making company, ... we were even at the beginning of 2002 a highly profitable company, afterwards ... unfortunately, because one of our big customers, which we had had here as a part of a worldwide tender, ... Flextronics simply did not win that tender, ... and the production moved somewhere else. Thus, let's say that we were not that profitable, but we were still in the black.

... anyway, the reasons for this measure [departure] were outside of the Czech Republic ... here in the Czech Republic ... we were simply, I would say, in the wrong place at the wrong time, there was no other reason, essentially.

Flextronics' decision to leave the locality was based on remote events (the world crisis); accordingly, the locality could not in any way influence the factors or events upon which the decision to leave was based. Consequently, the political debate in the locality was limited mainly to the struggle over the distribution of symbolic responsibility for the departure of Flextronics, which was perceived as a grand failure.

One might conclude that the locality is thus asymmetrically dependent upon events that it cannot influence. However, if we look at the case in more detail, this conclusion is simplistic and inadequate. The most interesting feature of this asymmetric, one-way dependence is its dialectics. In this case, local events were not directly shaped by remote causes. On the contrary, the local situation was the opposite of that occurring at a distance. Particularly during the deep crisis in the world market the local branch of Flextronics was highly profitable. The company's decision to leave the locality was based on remote factors (market crisis); nevertheless, it was made in the context of local prosperity.

We are dealing here with a situation in which the remote or the 'global' is a source of uncertainty for local actors. It corresponds to Bauman's account of power relations in contemporary capitalism (see above). In the Flextronics story, local actors could have little influence on the remote factors that determined local events, but the locality's prospects were independent of local prosperity or decline (whatever its causes). It was therefore almost impossible for local officials to anticipate future economic development - should they base their predictions on local success or remote crisis? Accordingly, the only explanation of events that they can offer is that the 'corporation decided', which is actually an adequate explanation.

\section{[Expert \#1 of RDASM:]}

Simply, after a certain amount of time, Flextronics suddenly changed its plans, it was claimed that it was actually a decision by the management of Flextronics that the Hungarian branch was preserved and here production was reduced ... 
Do you have any explanation as to why the firm decided to leave the Brno locality? These are speculations, no one could tell you exactly why they decided to leave, simply, I would say, it was a decision of management.

\subsection{The relation between the region and the TNC: where is the bargaining power?}

As the nation state is 'hollowing out' and transnational economic actors are emerging amidst post-Fordist circumstances, the regional-TNC nexus is becoming a salient aspect in relations between the economic and political systems [Jessop 1994]. Let us consider the distribution of power in the relation between the TNC and the region in the case of the Flextronics' investment.

The interviewed officials did not concur on this issue. Experts from the RDASM found the bargaining relation that the region and the TNC were in to be generally asymmetric, while CzechInvest's experts did not.

\section{[Expert \#2 of RDASM:]}

It is clear that the nature of the relation is that investors can materialise anywhere; however, we should not lower the [social and regulatory standards] we ourselves define.

Thus, the relation is asymmetric.

\section{[Expert \#1 of CzechInvest:]}

When speaking about the power relation between these corporations and the state ...

Why do you consider it a power relation?

The story of Flextronics allows us to make several points in support of the thesis that power in the relation between the TNC and the region is unequally distributed in the TNC's favour. First, as was demonstrated in the previous section, the TNC ('the remote') is a source of uncertainty for the region ('the local'). Second, the very policy of investment incentives is another source of the TNC's power [Beck 2000b]. Accordingly, Flextronics was freed from paying taxes and received other subsidies that helped it to minimise its costs (the training of employees, the transfer of land). Third, investment incentives are an essential aspect of 'global horse-trading' - the competition between localities to lure investors. Indeed, this case study shows that a) regions are generally considered to be in a situation of competition with each other over luring investors (e.g. the local politicians and media viewed this investment-luring process in the context of competing with a possible investment site in Hungary), and b) capital continually evaluates the activity of regions - it gives 'signals' to investors (see below). Regions are in a situation in which they can be rewarded or punished for their activity by investors, who can either bring capital to the locality or withdraw it (e.g. CzechInvest's director was unhappy when Brno cancelled the contract about the land transfer in case it would discourage other prospective investors). Both these facts are important sources of a TNC's power and bargaining potential. 
[Hugh Kelly of Flextronics, Mladá Fronta Dnes 7 August 2002]

We do not understand why the city is implementing these measures. .... A significant precedent will arise for the future and it will send out a negative signal. It will mean that the business environment is unstable. It will complicate our situation in looking for a compensatory investor.

\section{[Expert \#1 of RDASM:]}

The region attracts an investor through its behaviour. If the local government is qualified, if it is able to perceive the business priority of the investors, then, simply, quality arrives [i.e. investors, who bring value to a locality].

As a consequence, the norm of providing incentives and further assistance to capital emerged. TNCs expect that states or regions will assist and subsidise their activity. The reluctance to do so, or 'unpreparedness', is enough reason to invest somewhere else.

\section{[Expert \#1 of CzechInvest:]}

Currently, virtually every state in Europe has its own investment agency and provides investment incentives to companies. At present, any state that does not provide investment incentives is almost automatically disqualified, it means ... this is one of the factors that creates the balance in such a way that without it the balance would be lost.

\section{[Manager of Flextronics:]}

Considering that the Czech Republic was not yet equipped with any investment incentives at that time, it [Flextronics] chose Hungary, which offered de facto tax holidays ... Finally, we selected Brno, ... this locality was perfect because of its location; on the other hand, it was unprepared and, for instance, the city council was not experienced in assisting, but this was compensated for by the fact that we were already present in $\mathrm{Br}-$ no, thus we were familiar with the local environment ...

and, to be honest, Brno wasn't recommended to us, indeed, given that it was not prepared.

\subsection{Towards the economic system's ecological dominance?}

Some indicators regarding the economic system's ecological dominance were mentioned above. The capacity to distantiate and compress time-space is what enabled Flextronics to escape the control capacities of the locality and the nation state. In addition, a semantic dominance exerted by the economic system can also be observed.

The semantic dominance is reflected in the way the state actors interpret the environment in which they formulate their strategy. The semiotic representation of the economy that the interviewed policy makers have is dominated by the image of 
'globalisation' [cf. Hirst and Thompson 1999]. According to them, this process indisputably exists. CzechInvest's view is of a borderless, 'fully globalised' economy an economy into which the Czech Republic is fully integrated and which puts substantial constraints on local policy options. ${ }^{10}$

Economic dominance is also reflected in the language and logic that CzechInvest's officials use to grasp social reality. ${ }^{11}$ The economic logic used by the state could be observed in the way it formulated the contract with Flextronics and evaluated the very story of electronics investment. The demands made by the state in the incentive contract were formulated according to economic logic - the state's requests were mainly monetary (to invest 10.6 million USD ${ }^{12}$ ). Accordingly, CzechInvest evaluated the Flextronics story in terms of crude financial cost-benefit analysis. ${ }^{13}$

The semantic hegemony of the economic system is also reflected in the way in which CzechInvest's officials think about social reality. In analysing and evaluating social reality, such as competition between regions, they are reluctant to engage criteria other than economic (e.g. economic growth). They grasp social reality merely through economic concepts and comparisons (e.g. market, supply and demand). CzechInvest's officials refuse to distinguish between economic and political or social spheres and their respective logics (e.g. they do not see a difference between the state and the firm).

\section{[Expert \#1 of CzechInvest:]}

With regard to the policy [of FDI-luring], it is the same as if a firm decided to stop advertising its car and supporting the advertising industry, because it would consider this as influencing the customer. It would sell and produce cars without spending a crown on advertising. You can imagine the position of such a firm in competition with other auto factories.

However, one could object that the state is not a firm.

And what is the state?

\section{[Expert \#1 of CzechInvest:]}

Do you view it as a problem that there is, as you say, a situation in which different states with different social standards compete globally to lure capital? [abridged]

\footnotetext{
${ }^{10}$ Neither CzechInvest nor RDASM supported their arguments with any analysis of the extent to which economic activity has been internationalised. The experts at CzechInvest based their arguments mainly on 'general numbers'. However, RDASM's experts implicitly referred to some of the debates going on in the social sciences over contemporary social change.

11 This assertion is not tenable in RDASM's case. Paradoxically, the officials at this partly private institution do not employ economic logic and language as much as their state colleagues do.

${ }^{12}$ In addition, Flextronics was required to train 225 workers and build an electronics-manufacturing plant.

13 According to this analysis, the direct profit of Flextronics' investment was approximately 648 million CZK (see www.czechinvest.org for details).
} 
This is a typical example of supply and demand. For instance, in Singapore, thanks to the fact that their products are successful, the demand for their workforce will increase, and the supply of people that are willing to work for relatively low wages will decrease. As a consequence, there will be an equilibrium on a higher level. This means that the economy of Singapore will advance. ... Therefore, the price and level of social standards will come closer to the European conception.

As a result of this, the market is attributed nearly universal capabilities - e.g. it evaluates the appropriateness of social standards and market regulation.

\section{[Expert \#1 of CzechInvest:]}

... if France reached this stage when the employees, the unions, and the state in general were exacting too generous a social system from firms, which the firms were unable to cover, then, evidently, some change has to happen. Currently, the economy of France suffers owing to this. It is necessary to view it in the sense that some balance must to be achieved.

Thus, as you say, the firms determine the balance; they decide what a too generous welfare state is?

That is determined by the world economy.

To conclude, the semantic dominance is an importance aspect of the capacity of the economic system to enforce its logic on the political system. The story of Flextronics offers some indicators of the semantic dominance of the economic system, such as the economic language and logic that CzechInvest's officials used to grasp social reality.

\section{Conclusion}

This paper attempted to introduce and demonstrate the utility of the form-analytic, strategic-relational approach for empirical research in the Czech Republic. It also tried to show the relevance of the theories of post-Fordism in the context of the Czech Republic and ECE. I presented selected findings of my case study of Flextronics' investment in Brno, which focused on the relation between the investor, on the one hand, and the state and city, on the other hand.

The story of Flextronics' investment was interpreted here as a post-Fordist interaction between an economic and political system. The efforts of the state and the city to attract Flextronics to the locality and the following state-city-TNC interaction are post-Fordist economic interventions: Schumpeterian supply-side management. The state and municipality tried to promote the competitiveness of the region through investment incentives. The analysis of the scalar dimension of this interaction demonstrated how the political system was transformed in the process of scale relativisation. An investigation was also made into the nature of the relation be- 
tween the TNC and the region. This relation was found to be unequal and to the region's disadvantage. The article showed that there was no one-way dependence between the region and the TNC, but rather a relation of complex dialectic interdependence. The power of the TNC was based on the competition between localities to lure investors and the nature of this power corresponds to Crozier's domination strategy. It was concluded that the story of the Flextronics' investment and the way the state officials grasped, interpreted, and evaluated the story give tentative indications that the economic system is tending towards ecological dominance.

The form-analytic theory of post-Fordism and post-Fordist governance was employed uncritically without taking into account the particularities of Czech capitalism. Unfortunately, there is no ECE-specific conceptual apparatus and this is a fundamental gap in the comparative theory of capitalism from the perspective of form-analytic, strategic-relational approach. I hope that this article will provide incentives for rethinking the theories of post-Fordism in order to theorise about the particular, local articulation of capitalism(s) in the ECE region. ${ }^{14}$

JAN DRAHOKOUPIL is a PhD candidate at the Department of Sociology and Social Anthropology of the Central European University in Budapest. He is currently working on the project 'Meanings of Capital: Actors, Strategies, and Struggles around FDI in the Czech Republic', which investigates the emergence and properties of the developmental project based on attracting (foreign) investment in the Czech Republic and analytically, the contribution of discourse to the construction of the capitalist economy and state. He is also interested in the form-analytic theories of capitalism(s) in East-Central Europe.

\section{References}

Altvater, E. 1998. “Theoretical Deliberations on Time and Space in Post-Socialist Transformation." Regional Studies 32:591-605.

Bauman, Z. 1998a. Globalization. The Human Consequences. Cambridge: Polity Press.

Bauman, Z. 1998b. “On Globalization: Or Globalization for Some, Localization for Some Others." Thesis Eleven 54: 37-49.

Beck, U. 2000a. "The Cosmopolitan Perspective: Sociology of the Second Age of Modernity." British Journal of Sociology 51 (1): 79-105.

Beck, U. 2000b. What Is Globalization? Cambridge: Polity Press.

Brannen, J. 1992. "Combining Qualitative and Quantitative Approaches: An Overview." Pp. 3-37 in Mixing Methods: Qualitative and Quantitative Research, edited by J. Brannen. Aldershot: Averbury.

Boyer, R. 1990. The Regulation School: A Critical Introduction. New York: Columbia University Press.

Boyer, R. and Y. Saillard. (eds.) 2002. Regulation Theory: The State of the Art. London: Routledge.

${ }^{14}$ For some attempts to draw on, see Altvater [1998] and Pickles and Smith [1998]. 
Castells, M. 1996. The Rise of Network Society. Oxford: Blackwell.

Cerny, P. G. 1995. "Globalization and the Changing Logic of Collective Action." International Organization 49 (4): 595-625.

Chouliaraki, L. and N. Fairclough. 1999. Discourse in Late Modernity: Rethinking Critical Discourse Analysis. Edinburgh: Edinburgh University Press.

Dicken, P. 1994. "Global-Local Tensions: Firms and States in the Global Space-Economy." Economic Geography 70 (2): 101-128.

Dicken, P. 1997. “Transnational Corporations and Nation-states." International Social Science Journal 151: 77-89.

Ellingstadt, M. 1997 "The Maquiladora Syndrome: Central European Prospects." Europe-Asia Studies 49 (1): 7-21.

Fairclough, N. 1992. Discourse and Social Change. Cambridge: Polity Press.

Fairclough, N. 1995. Critical Discourse Analysis: The Critical Study of Language. London and New York: Longman.

Fairclough N., B. Jessop and R.A. Sayer. 2003. “Critical Realism and Semiosis.” Pp. 23-42 in Realism, Discourse and Deconstruction, edited by J.M. Roberts and J. Joseph. London: Routledge.

Griamsci, A. 1971. Selections from the Prison Notebooks. New York: International Publishers.

Hirst, P. and G. Thompson 1999. Globalization in Question. (2nd edition.) Cambridge: Polity Press.

Jessop, B. 1990a. State Theory: Putting the Capitalist State in Its Place. Cambridge: Polity Press.

Jessop, B. 1990b. "Regulation Theories in Retrospect and Prospect." Economy and Society 19: 153-216.

Jessop, B. 1994. "Post-Fordism and the State." Pp. 251-279 in Post-Fordism. A Reader, edited by A. Amin. Oxford: Blackwell.

Jessop, B. 1995. "The Regulation Approach, Governance and Post-Fordism: Alternative Perspectives on Economic and Political Changes." Economy and Society 24: 303-333.

Jessop, B. 2000a. "The Crisis of the National Spatio-Temporal Fix and the Tendential Ecological Dominance of Globalizing Capitalism." International Journal of Urban $\mathcal{E}$ Regional Research 24 (2): 323-360.

Jessop, B. 2000b. "The State and the Contradictions of the Knowledge-Driven Economy." Pp. 63-78 in Knowledge, Space, Economy, edited by J.R. Bryson, P.W. Daniels, N.D. Henry, and J. Pollard. London: Routledge.

Jessop, B. 2002a. "Time and Space in the Globalization of Capital and Their Implications for State Power." Rethinking Marxism 14 (1): 97-116.

Jessop, B. 2002b. The Future of the Capitalist State. Cambridge, UK and Malden, MA: Polity Press.

Ostry, S. 1990. Governments and Corporations in a Shrinking World. New York: Council on Foreign Relations.

Pavlínek, P. 1998. "Foreign Direct Investment in the Czech Republic." Professional Geographer 50: 71-85.

Pavlínek, P. And A. Smith. 1998. "Internationalization and Embeddedness in East-Central European Transition: The Contrasting Geographies of Inward Investment in the Czech and Slovak Republics." Regional Studies 32: 619-38.

Pickles, J. and A. Smith (eds.) 1998. Theorising Transition: The Political Economy of PostCommunist Transformations. London and New York: Routledge.

Poulantzas, N. 1978. State, Power, Socialism. London: New Left Books.

Reich, R. B. 1991. The Work of Nations: Preparing Ourselves for 21st-Century Capitalism. New York: Vintage Books.

Sayer, R.A. 2000. Realism and Social Science. London and Thousand Oaks: Sage. 
Strange, S. 1996. The Retreat of the State: The Diffusion of Power in the World Economy. Cambridge: Cambridge University Press.

Tickell, A. and J. A. Peck 1995. "Social Regulation after Fordism: Regulation Theory, Neo-liberalism and the Global-local Nexus." Economy and Society 24 (3): 357-386. Yin, R. K. 1989. Case Study Research: Design and Methods. Thousands Oaks, CA: Sage.

\section{Other Sources}

Mladá Fronta Dnes, 13 July 2002. "Odchod investora může ovlivnit volby." (The departure of the investor could influence the elections.) (p. 1)

Mladá Fronta Dnes, 7 August 2002. "Brno vyhlásilo boj Flextronicsu." (Brno declares war on Flextronics.) (p. 3)

Official website of Flextronics (www.flextronics.com). 